\title{
Treating 'Trifles': the Indigenous Adoption of European Material Goods in Early Colonial Hispaniola (1492-1550)
}

\author{
Floris W.M. Keehnen
}

Early colonial encounters with Europeans introduced indigenous Caribbean peoples to a wide array of foreign goods and materials. Through gift-giving and exchange, objects form vital elements for negotiating the social, cultural, and material boundaries between peoples with vastly different cultural-historical backgrounds (e.g., Cipolla 2017; Gosden 2004; Maran and Stockhammer 2012; Thomas 1991). In the Caribbean, these exotic items often possessed qualities similar to or commensurable with the preexisting values of indigenous societies, facilitating their intercultural transfer and adoption (Keehnen 2011, 2012; Oliver 2000; Saunders 1999). The blending of new and traditional material expressions ushered in a period of creativity and innovation, in which the material culture repertoires of all those involved in the colonial process increasingly transformed.

European trade goods were offered to indigenous Caribbean peoples within days after first encounter on 12 October 1492 at the island of San Salvador, The Bahamas (Dunn and Kelley 1989, 83-85; see also Berman and Gnivecki this volume). Christopher Columbus' log of his first voyage in addition to the accounts from traveling companions and other contemporaries vividly describe how such material interactions continued throughout the early colonial period. An analysis of a standard corpus of late fifteenth- and early sixteenth-century (ethno)historical sources pertaining to the Greater Antilles and Bahamas has identified a total number of 177 such (reciprocal) gift-giving, barter, and tribute events in which objects transfer between cultural groups (Keehnen and Mol 2018). The vast majority of these transactions took place within the first 5-year period of colonial interaction and these involved at least 137 different types of objects, 61 of which are of European origin. ${ }^{2}$

1 This chapter is largely based on the archaeological data presented and discussed in the $\mathrm{PhD}$ dissertation Values and Valuables by Floris Keehnen (forthcoming).

2 As part of the construction of the database used for this analysis, descriptions of transaction events have been cross-referenced where possible to account for the fact that many times the

(C) FLORIS W.M. KEEHNEN, 2019 | DOI:10.1163/9789004273689_004

This is an open access chapter distributed under the terms of the CC-BY-NC-ND 4.0 License, 
The nature, purpose, and desirability of early colonial trade rapidly changed over these years as Columbus' originally mercantile venture transitioned into an imperial project of conquest and colonization that incorporated all of the Greater Antilles (Deagan and Cruxent 2002a; Valcárcel Rojas et al. 2013; Wilson 1990; see also Valcárcel Rojas this volume). From a material perspective, the (minimal) variety of European-introduced objects that indigenous communities would have had direct access to is striking. In these historically documented exchanges, the most prominent European trade wares were beads and hawk bells - the basic constituents of what Jeffrey Brain (1975) defined as the standard European "gift kit". The hardness, luminosity, and lustrousness of glass and metal items were considered important material traits in precolonial Caribbean cultures and societies and would have enabled exotic things such as beads and bells to tap into indigenous systems of value easily (Keehnen 2011, 2012; Oliver 2000; Saunders 1999). Other object types mentioned include varieties of food, clothing, weapons, and personal items.

The (ethno)historical records provide valuable data on the connection and integration of the indigenous Caribbean and European material realms. However, they are less informative when it comes to the indigenous use and appropriation of European-derived objects after their initial reception. Did such foreign items retain the importance or connotations they were valued for when exchanged with the Spaniards? Or did their status, meanings, and functions change once absorbed within a new cultural context?

In this chapter I will present a general overview of the archaeological data currently available for the island of Hispaniola (divided between the modern nations of Haiti and the Dominican Republic) in relation to the indigenous handling and incorporation of European objects in early colonial times (1492-1550). Hispaniola was the earliest and prime locus of prolonged indigenous-European interaction in the Americas in the decades following first contact. The dynamics of progressing European colonization and indigenous responses were different here than in other parts of the Greater Antilles, where the Spanish achieved domination in much shorter time (see Valcárcel Rojas et al. 2013). Although this provides Hispaniola a unique position for research into the very beginnings of the entanglement between these two distinct cultural entities, this period of the island's history has archaeologically remained understudied. Here, I will discuss the archaeological sites of En Bas Saline (Haiti), El Variar, and Juan Dolio (Dominican Republic) to reveal and explore some of the material complexities of indigenous-European interaction in the Caribbean.

same event was narrated, registered, or repeated by different chroniclers. For more detailed information about the approach taken, as well as the documentary sources consulted, see Keehnen and $\mathrm{Mol}$ (2018). Here, the numbers are mainly meant to illustrate the rich material variety of the early colonial encounters in the Caribbean. 
Since the 1970s and 1980s, colonial-period archaeology in Hispaniola has largely concentrated on the island's main foci of Spanish activity, including the towns of La Isabela (Caro Alvarez 1973; Deagan and Cruxent 2002a, 2002b; Luna Calderón 1986), Concepción de la Vega (Deagan and Cruxent 2002b; Kulstad 2008, 2015; Ortega and Fondeur 1978), Puerto Real (Deagan 1995), and Santo Domingo (Olsen Bogaert et al. 1998; Ortega 1982), as well as sugar mills in Azua and Sanate (Chanlatte Baik 1978; Mañón Arredondo 1978; Tavárez María 200o) and the gold mining complex at Pueblo Viejo de Cotuí (Olsen Bogaert 2011; Olsen Bogaert et al. 2011). The extensive and pioneering work of Kathleen Deagan and colleagues (e.g., Deagan 1995; Deagan and Cruxent 2002a, 2002b), as that of numerous others, have been instrumental for our understanding of European adaptive strategies in the Caribbean and the development towards a mixed colonial society (Deagan 2003). At the same time, efforts to scrutinize indigenous experiences and transitions outside of these Spanish-based centers have been limited, in contrast to, for instance, archaeological investigations in Cuba (Domínguez 1978; Valcárcel Rojas 1997, 2016, this volume). Reasons for the current lack of data can be found in methodological challenges in site identification and the long dominant assumption of an annihilated indigenous population (Deagan 2004).

This does not mean we do not know anything about the ways indigenous communities integrated European objects into their lives. Incidental findings of Spanish-introduced materials have been reported by archaeologists excavating sites they initially regarded as precolonial. Key sites in Dominican archaeological history such as Atajadizo, Juan Dolio, and La Cucama have all yielded items of European origin, which archaeologists have discussed within their local archaeological context. Some researchers have indeed tried to come to more general interpretations of the indigenous use and valuation of European goods (Deagan 1988; García Arévalo 1978a; Vega 1979). Nevertheless, a comprehensive synthesis of the pertinent data collected over the many decades of Hispaniolan archaeology has hitherto been lacking.

A review of the available literature reveals that, based on the presence of European materials, more than thirty indigenous sites have thus far been identified as having persisted into early colonial times (Figure 3.1; Table 3.1). The core archaeological component of these sites is indigenous. However, we should be aware that the complexities of this period may compromise the way we define and single out "indigenous spaces" as opposed to "mixed" or "colonial spaces" (cf., Lightfoot et al. 1998; Silliman 2010). Indigenous territories increasingly became shared and entangled spaces as the Spanish conquest and colonization of the island progressed. In terms of European-introduced objects, it cannot 
always be ascertained whether these were in fact handled by indigenous peoples. Also, growing power imbalances could have jeopardized indigenous selfdetermination with respect to the adoption and use of foreign material culture. This and other colonial influences, as well as diverging indigenous experiences on both the individual and community levels, are not easily translated into altered material patterns.

Looking at the geographical distribution of early colonial indigenous sites presented in Figure 3.1, we see the highest concentration of sites in the Dominican Republic, in particular the country's eastern and southern halves. Currently, only two Haitian sites are known (En Bas Saline and Île à Rat), although archaeological research in the country has been minimal compared to what has been done in the Dominican Republic. The sites on the map are located both in relative proximity to early Spanish settlements, as well as in

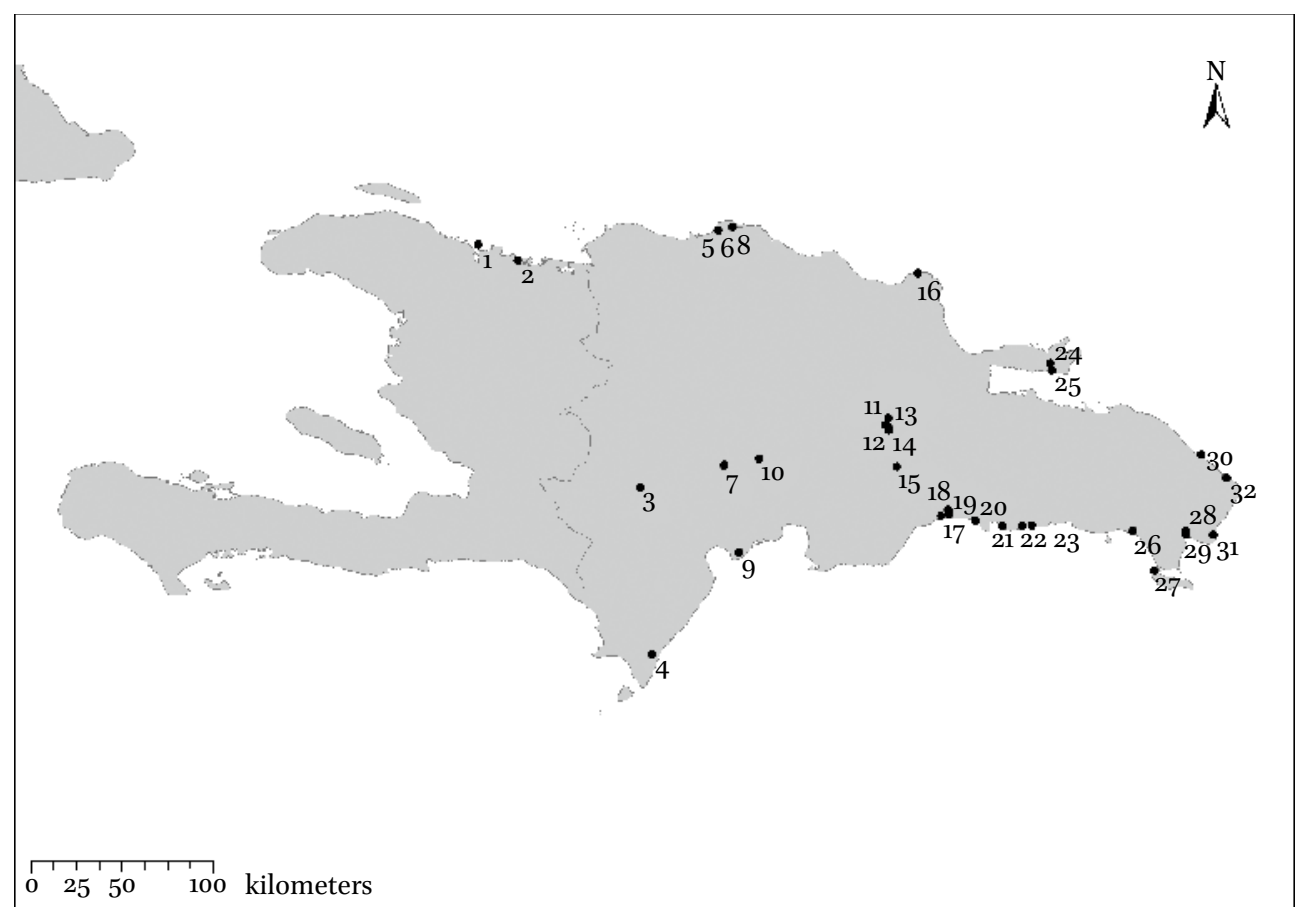

FIGURE 3.1 Map showing the locations of early colonial indigenous sites on Hispaniola:

(1) Île à Rat; (2) En Bas Saline; (3) Majagual; (4) El Saladito; (5) Bajabonico;

(6) El Perenal; (7) Sabana Yegua; (8) Los Balatases; (9) El Variar; (10) Guayabal;

(11) Loma Piedra Imán de los Cacaos; (12) Las Lagunas; (13) Sabana del Rey (sites 12-15); (14) El Rayo; (15) Yamasá; (16) Playa Grande; (17) Antigua Calle Juan Barón;

(18) Mendoza, Villa Faro; (19) Los Tres Ojos; (20) La Caleta; (21) La Cucama;

(22) Guayacanes; (23) Juan Dolio; (24) Rio San Juan; (25) Anadel; (26) Boca de Chavón; (27) Punta Catuano, Isla Saona; (28) Atajadizo; (29) Boca de Yuma;

(30) Punta Macao; (31) El Cabo; (32) Playa Bávaro 
more distant and isolated areas in the island's northeast and southwest. About a dozen of these sites were subjected to extensive (and sometimes multiple) excavations, while other places were only surveyed or tested. Locations at which European artifacts have been found comprise indigenous (ceremonial) plazas, households, burials, middens, and other activity areas, as well as more secluded spots such as caves and caches.

Unfortunately, most of the European objects - the majority collected in the 1970 s and 1980 - are only superficially described in the literature. Basic or even consistent artifact information (numbers, measurements, typology, etc.) is often lacking, as are context details (also unavailable due to poor stratigraphy and minimal use of fine sieving) and attempts at their social interpretation, hampering precise dating and detailed comparative analyses. In a general sense, however, many of the recovered materials typically consist of sherds of Spanish majolica, olive jar, and other types of glazed or unglazed coarse earthenware, as well as glass and metal items (Table 3.1). The most

TABLE 3.1 Overview of European materials found at early colonial indigenous sites on Hispaniola

\begin{tabular}{|c|c|c|}
\hline Site & Materials reported & References \\
\hline Anadel & metal pin & $\begin{array}{l}\text { Krieger (1929); Vega } \\
(1979)\end{array}$ \\
\hline $\begin{array}{l}\text { Antigua Calle } \\
\text { Juan Barón }\end{array}$ & $\begin{array}{l}\text { majolica; glazed and } \\
\text { unglazed earthenware; } \\
\text { azulejos; tobacco pipes; } \\
\text { (decorated) glass fragments; } \\
\text { nails; seals; buckles; ring } \\
\text { bolts; coins (maravedíes); } \\
\text { buttons; scabbard tips; key }\end{array}$ & $\begin{array}{l}\text { Ortega }(2005) \text {; Ortega } \\
\text { and Fondeur (1978) }\end{array}$ \\
\hline Atajadizo & nails; glass & $\begin{array}{l}\text { Veloz Maggiolo et al. } \\
(1976)\end{array}$ \\
\hline Bajabonico & glass; earthenware & Guerrero (1999) \\
\hline Boca de Chavón & horseshoe & Hatt (1932) \\
\hline Boca de Yuma & Columbia Plain majolica & Goggin (1968) \\
\hline El Cabo & $\begin{array}{l}\text { Columbia Plain majolica; } \\
\text { early-style olive jar; Nueva } \\
\text { Cádiz beads; metal and glass } \\
\text { fragments }\end{array}$ & Samson (2010) \\
\hline
\end{tabular}




\begin{tabular}{|c|c|c|}
\hline Site & Materials reported & References \\
\hline El Perenal & unspecified & $\begin{array}{l}\text { Deagan and Cruxent } \\
(2002 b)\end{array}$ \\
\hline El Rayo & $\begin{array}{l}\text { Blue on White majolica; early- } \\
\text { style olive jar; earthenware }\end{array}$ & $\begin{array}{l}\text { Olsen Bogaert (2013a; } \\
2013 b)\end{array}$ \\
\hline El Saladito & glass; earthenware & López Rojas (199o) \\
\hline El Variar & metal sheets and fragments & $\begin{array}{l}\text { Ortega and Fondeur } \\
(1976)\end{array}$ \\
\hline En Bas Saline & $\begin{array}{l}\text { musketball; copper alloy tin- } \\
\text { klers; scabbard tip fragment; } \\
\text { Columbia Plain majolica; } \\
\text { melado ware; bizcocho ware; } \\
\text { glass and metal fragments }\end{array}$ & $\begin{array}{l}\text { Cherubin (1991); Deagan } \\
(2004) \text {; Florida } \mathrm{Mu}^{-} \\
\text {seum of National History } \\
(2017)\end{array}$ \\
\hline Guayabal & unspecified & Ortega $(2005)$ \\
\hline Guayacanes & unspecified & De Boyrie Moya (196o) \\
\hline Île à Rat & earthenware; brick & Keegan $(2001)$ \\
\hline Juan Dolio & $\begin{array}{l}\text { Columbia Plain, Caparra } \\
\text { Blue, Isabela Polychrome, } \\
\text { Yayal Blue on White, Blue on } \\
\text { White, Hispano-Moresque } \\
\text { lusterware and cuerda seca } \\
\text { majolica types; early-style } \\
\text { olive jar; melado, Morisco } \\
\text { green, and other types of } \\
\text { glazed wares; transcultural } \\
\text { ceramics; bronze buckle; } \\
\text { metal 'threepointers' (indig- } \\
\text { enous ritual items) }\end{array}$ & $\begin{array}{l}\text { Florida Museum of } \\
\text { National History (2017); } \\
\text { Garcia Arévalo (1978a; } \\
\text { 1990; 1991); Garcia } \\
\text { Arévalo and Morbán } \\
\text { Laucer (1971); Goggin } \\
\text { (1960; 1968); Morbán } \\
\text { Laucer and Garcia } \\
\text { Arévalo (1971); Ortega } \\
\text { (20o2); Ortega and } \\
\text { Fondeur (1978); Veloz } \\
\text { Maggiolo (1980; 1993) }\end{array}$ \\
\hline La Caleta & $\begin{array}{l}\text { Columbia Plain, blue on } \\
\text { white and cuerda seca } \\
\text { majolica types }\end{array}$ & Goggin (1968) \\
\hline La Cucama & $\begin{array}{l}\text { early-style olive jar; Isabela } \\
\text { Polychrome and possibly } \\
\text { other types of majolica; } \\
\text { melado ware; transcultural } \\
\text { ware; earthenware; coin } \\
\text { (maravedi) }\end{array}$ & $\begin{array}{l}\text { García Arévalo (1978a); } \\
\text { Mañón Arredondo et al. } \\
\text { (1971); Ortega (2005); } \\
\text { Veloz Maggiolo et al. } \\
\text { (1973) }\end{array}$ \\
\hline Las Lagunas & metal book clasp & Olsen Bogaert (2015) \\
\hline
\end{tabular}


TABLE 3.1 Overview of European materials found at early colonial indigenous sites on Hispaniola (cont.)

\begin{tabular}{|c|c|c|}
\hline Site & Materials reported & References \\
\hline $\begin{array}{l}\text { Loma Piedra } \\
\text { Imán de los } \\
\text { Cacaos }\end{array}$ & $\begin{array}{l}\text { musketball; glass } \\
\text { fragment; glazed and } \\
\text { unglazed earthenwares }\end{array}$ & Olsen Bogaert (2015) \\
\hline Los Balatases & metal (spear)point & $\begin{array}{l}\text { Ulloa Hung and Herrera } \\
\text { Malatesta }(2015)\end{array}$ \\
\hline Los Tres Ojos & unspecified & $\begin{array}{l}\text { Garcia Arévalo and } \\
\text { Morbán Laucer (1971) }\end{array}$ \\
\hline Majagual & metal beads & García Arévalo (1978a) \\
\hline $\begin{array}{l}\text { Mendoza, Villa } \\
\text { Faro }\end{array}$ & $\begin{array}{l}\text { green lebrillo; roof tiles; } \\
\text { earthenware }\end{array}$ & Ortega $(2005)$ \\
\hline Playa Bávaro & early-style olive jar & Ortega $(1978)$ \\
\hline Playa Grande & $\begin{array}{l}\text { Columbia Plain, Isabela } \\
\text { Polychrome and cuerda seca } \\
\text { majolica; melado ware; early- } \\
\text { style olive jar; earthenware; } \\
\text { coin (maravedî); glass bead; } \\
\text { bead manufactured from } \\
\text { sherd of glazed ware; nails; } \\
\text { knife; metal plates; buck- } \\
\text { les; fasteners; horseshoes; } \\
\text { glass and metal fragments; } \\
\text { clay pipe with indigenous } \\
\text { decoration }\end{array}$ & $\begin{array}{l}\text { López Belando (2012; } \\
2015)\end{array}$ \\
\hline $\begin{array}{l}\text { Punta Catuano, } \\
\text { Isla Saona }\end{array}$ & earthenware & $\begin{array}{l}\text { Vega and Luna Calderón } \\
(2004)\end{array}$ \\
\hline Punta Macao & $\begin{array}{l}\text { Columbia Plain majolica; } \\
\text { earthenware }\end{array}$ & Atiles (2004) \\
\hline Rio San Juan & iron hammer & $\begin{array}{l}\text { Smithsonian National } \\
\text { Museum of Natural } \\
\text { History (2017); James } \\
\text { Krakker, pers. comm. } \\
2017\end{array}$ \\
\hline $\begin{array}{l}\text { Sabana del Rey } \\
(\text { sites 12-15) }\end{array}$ & $\begin{array}{l}\text { early-style olive jar; } \\
\text { Columbia Plain majolica; } \\
\text { glazed ware }\end{array}$ & $\begin{array}{l}\text { Olsen Bogaert (2013a; } \\
2015 \text { ) }\end{array}$ \\
\hline
\end{tabular}




\begin{tabular}{lll}
\hline Site & Materials reported & References \\
\hline Sabana Yegua & $\begin{array}{l}\text { hawk bells; metal sheets; } \\
\text { buckles; stirrup rings; metal } \\
\text { base of a lamp } \\
\text { majolica }\end{array}$ & Vega (1979) \\
& & $\begin{array}{l}\text { García Arévalo and } \\
\text { Morbán Laucer (1990) }\end{array}$ \\
\hline
\end{tabular}

common ceramic forms are household, tableware, and kitchen utility wares such as plates, (carinated) bowls, jars, and basins. Metal objects have been identified in about twenty different varieties, yet from this assortment only coins, rings, and bells also feature in (ethno)historical descriptions of indigenous-Spanish transactions (Keehnen and Mol 2018). Moreover, despite their prominence in the documentary record, brass bells and glass beads are archaeologically virtually invisible. Bells were retrieved from a cache at Sabana Yegua (Vega 1979), while blue-colored beads were found only at the villages of El Cabo and Playa Grande (Hofman et al. 2014; López Belando 2015; Samson 2010, 282-284). Finally, the European artifacts form part of a variety of material compositions, they occur in their original or a reworked state, and appear to have been treated differently across space and time (see sections below).

\subsection{Other Expressions of the Material Encounter}

Apart from the European artifacts recovered from the early colonial sites inventoried here, evidence of the incorporation of European elements within the indigenous (socio-)material world can also be seen expressed differently. A cotton belt in Vienna's Museum für Völkerkunde and the so-called beaded cemí in Rome's Museo Nazionale Preistorico Etnografico Luigi Pigorini are two of the finest surviving masterpieces from the Caribbean (Ostapkowicz 2013; Taylor et al. 1997; Vega 1973). Both objects were indigenous valuables of high symbolic importance that most likely originate in early sixteenthcentury Hispaniola. The artworks are strikingly similar in their design and manufacture, characterized by elaborately braided cotton elements covered with meticulously executed beadwork of mainly white and red marine shells. Their uniqueness is further attested by the incorporation of European materials such as jet, brass pins, Venetian mirrors, and blue and green glass beads, which, with the exception of jet, were typical commodities of exchange in 
indigenous-Spanish encounters. Although many questions about the context and meaning of the two enigmatic objects are still unanswered, the integration of new and foreign materials into these aesthetically indigenous items uniquely illustrates the post-1492 transformation of the indigenous material culture repertoire.

A different way in which the presence of Europeans translated itself into the indigenous material record can be observed in a handful of caves across the Dominican Republic, where European persons, animals, and objects have been portrayed on the inner walls. Cueva de Rancho La Guardia holds pictographs of people dressed in Spanish manner (Abreu Collado 2008). In caves near the San Lorenzo Bay depictions of human figures holding spades have been found, along with those of horse or mule figures and chickens (Pagán Perdomo 1999). Horse pictographs are also seen in Cueva Mongó (Abreu Collado and Olsen Bogaert 1989) and the cave system of Pomier-Borbón, in the latter case joined by riders with lances (Guerrero and Veloz Maggiolo 1988). Representations of European ships occur in two locations: Cueva de la Arena in the San Lorenzo Bay complex (López Belando 2009) and the Cuevas del Pomier-Borbón (Schomburgk 1854). Although all of these images illustrate the indigenous engagement with 'the other', none of the places have yielded further evidence of their interaction with the Spanish. ${ }^{3}$

Many more aspects of the indigenous material domain were changed or affected as a result of the Spanish intrusion of the island, including foodways, ceramic production, and funerary rites. Especially when observed at indigenous sites we may assume that these alterations were not simply top-down impositions by the colonial power. At El Tamarindo, an indigenous village site close to La Isabela, residues of exotic plants and ruminant animals were found on indigenous ceramic sherds, suggesting that local communities incorporated European foods into their meals (VanderVeen 2006). No Spanish artifacts were discovered here. European faunal remains, most notably pig, were found at the sites of Antigua Calle Juan Barón, El Cabo, En Bas Saline, Loma Piedra Imán de los Cacaos, Playa Grande, and Punta Macao, although not all of the material has been confirmed to date to the late fifteenth or early sixteenth centuries (see Table 3.1). Indigenous ceramic repertoires underwent rapid changes, particularly when colonial rule manifested itself more strongly

3 It cannot be ruled out completely that these artistic expressions were made by Spaniards. Caves on Mona Island (located between the Dominican Republic and Puerto Rico) have provided evidence of European visitors interacting with indigenous wall paintings (Samson et al. 2016). 
(Ernst and Hofman 2015; García Arévalo 1978b, 1990, 1991; Ortega 1980; Ortega and Fondeur 1978). While the integration of indigenous and European pottery traditions is best seen within the Spanish colonial centers of the island, socalled transcultural ceramics - or indigenous-made vessels imitating Spanish styles and/or designs - are also known from the sites of Juan Dolio and La Cucama (see Table 3.1). The Cuban site of El Yayal represents a remarkable case, where traditional zoomorphic adornos (molded pot handles) were shaped into horse or cow figures (Deagan 1988; Domínguez 1984). Lastly, funerary rites also show a blending of indigenous and Spanish cultural customs. From a number of indigenous sites, including Guayacanes, Juan Dolio, and La Caleta, hispanicized burial patterns are known (Boyrie Moya 1960). Generally this implies a transition from placing the body in a traditional flexed position to one in which the interred person lies stretched with the arms crossed on the chest. In addition, grave goods may change in their composition and placement.

The Indigenous Adoption of European Material Goods: Three Archaeological Examples

The following case studies illustrate different ways in which European material goods are manifested in early colonial indigenous sites on Hispaniola. En Bas Saline, on the northcoast of Haiti, is the largest known indigenous site of the country and one of few systematically excavated places in the Greater Antilles with a continuous indigenous occupation across the historical divide from ca. AD 1250. The town was one of the first to be in contact with the Spanish and was situated close to an important Spanish center. El Variar is situated in the southwestern mountains of the Dominican Republic, an area long ignored by the Spanish and hence home to some of the last indigenous redoubts of the island. Juan Dolio is a sizeable cemetery-habitation site on the southeast coast of the island, located in an area of increased Spanish presence after the official relocation of their main port and settlement to Santo Domingo in 1498.

\subsection{En Bas Saline}

Located some 12 kilometers east of modern Cap Haïtien, En Bas Saline is believed to have been the residence of Guacanagarí, principal cacique or chief of the region, who provided shelter to Columbus and his crew after a fatal shipwreck in late 1492 (Deagan 2004). The village inhabitants were left relatively undisturbed by Spanish colonists until 1503, when only 2 kilometers away 
Puerto Real was founded (Deagan 1995). In the late 1970s, first archaeological work commenced, followed by large-scale excavations by Kathleen Deagan and her team in the 1980s (Cusick 1991; Deagan 1987, 1989, 1990, 2004). Although these campaigns were initially aimed at finding the short-lived Spanish fort of La Navidad, fine-grained excavation methods laid bare the post-1492 indigenous occupation of the site. The site's main features include an earthen ridge, refuse middens, and a central mound, located in the middle of a flat open area supposed to have functioned as a plaza or ball court. On top of the central mound two superimposed 15 meters wide house structures were identified. Three raised areas divide the plaza itself into two sections, interpreted as elite residence areas.

European materials at the site are scarce and generally unremarkable, comprising only 17 small fragments of glass, metal, and glazed earthenwares (Deagan 2004). Interesting, nevertheless, is that all but a piece of clear glass were found in the central mound, the residential area of the elites. The elite house further contained the highest number of indigenous ritual and ornamental items as well as the largest and most varied assemblage of pottery remains. Also the majority of European faunal remains were recovered here, including pigs (Sus scrofa), rats (Rattus rattus), mice (Mus musculus), and cats (Felis domesticus). In addition to these data, the online catalogue of the Florida Museum of National History (2017) has entries of a lead musket ball, a scabbard tip fragment, and a number of perforated copper alloy pendants. These items are not discussed in any of Deagan's publications and may have been part of earlier test excavations by William Hodges in the late $1970 s$.

\subsection{El Variar}

The locality of El Variar is situated near the town of Barreras in the south of the Dominican province of Azua. The only archaeological inquiry dates to 1975. Although no traces of past habitation could be discerned, a rich set of objects was found underneath a large rock of chert and limestone (Figure 3.2). The cache consisted of two small Chicoid vessels - one somewhat smaller than the other as to be placed on top of the larger one - that were traditionally used as containers of beverages or hallucinogenic powders in indigenous rituals and ceremonies (Ortega 2005, 240-244). Inside the covered pot were discovered a number of indigenous high-value objects, including an elaborate necklace of about 250 cylindrical-shaped stone and shell beads, and two anthropomorphic amulets, one made of stone, the other of shell. Interestingly, a natural resin was used to attach a small brass plate around the stone figure's neck. Also the eyes, as well as the shell figure's neck 


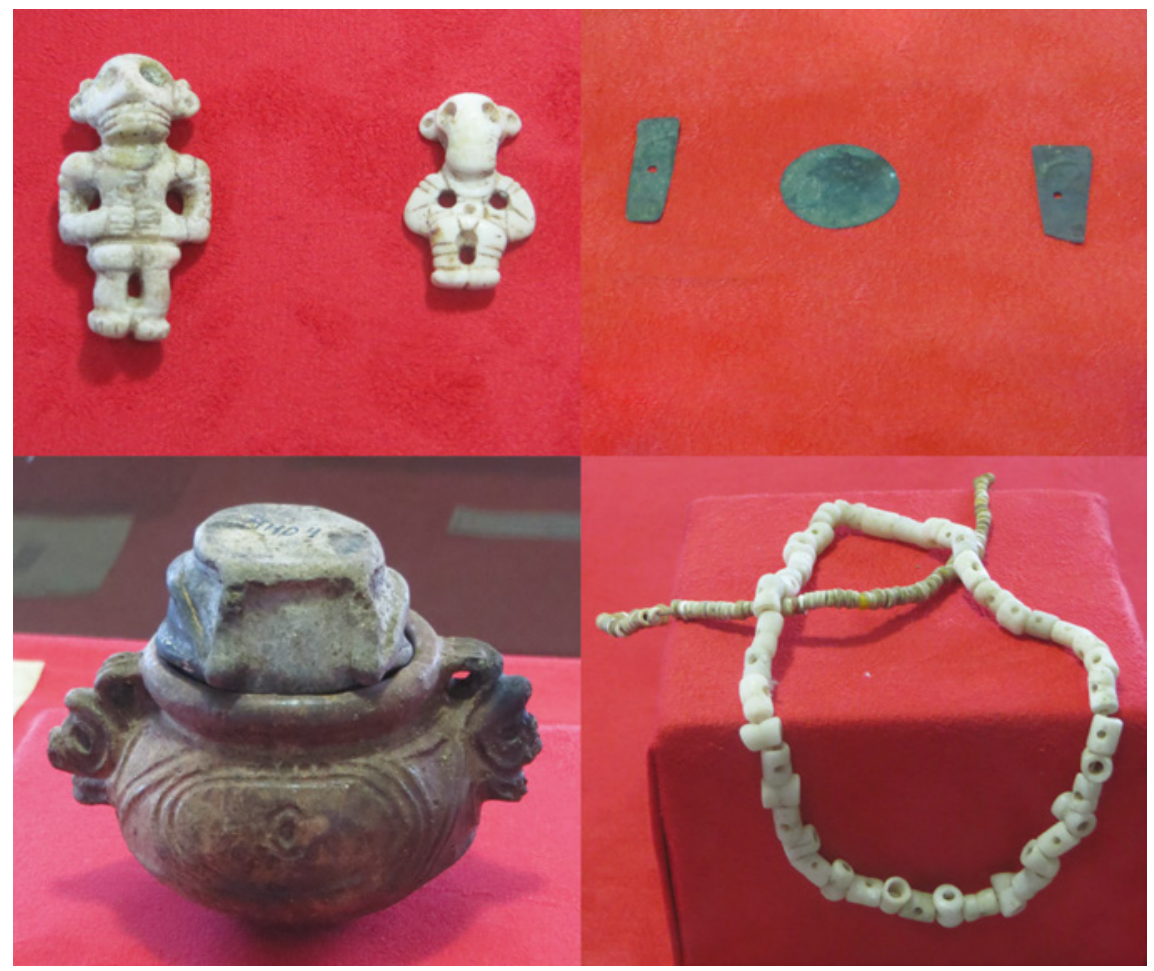

FIGURE 3.2 Cache of artifacts found at El Variar, Azua, Dominican Republic. Museo del Hombre Dominicano, Santo Domingo, Dominican Republic PHOTOS BY FLORIS W.M. KEEHNEN, NOT TO SCALE

showed signs of having had metal inlays or decoration. Besides, the assemblage included four brass items, two circular and two rectangular pieces, the latter perforated as to be worn as a pendant or to be inserted into the bead necklace (Ortega 2005, 240-244; see also Ortega and Fondeur 1976; Vega 1979).

\subsection{Juan Dolio}

Juan Dolio is located some 50 kilometers to the east of Santo Domingo and has an estimated indigenous occupation from $\mathrm{AD} 1000$ until at least the second decade of the sixteenth century. Most archaeological work was done between the early 1950s and 1970s, with a strong focus on the approximately one hundred burials at the site's cemetery areas (Boyrie Moya 1960; Drusini et al. 1987; Veloz Maggiolo 1972). While some of the graves contained indigenous offerings, only one skeleton also held Spanish goods (García Arévalo and Morbán Laucer 1971; Morbán Laucer and García Arévalo 1971). This individual, 
identified as a ca. 50-year old man, reflects traditional indigenous customs, such as cranial modification and a squatted position of the interred body. The grave goods consist of large and elaborate indigenous vessels placed next to the head, and, closer to the man's waist, a Spanish bowl of a ceramic type known as Columbia Plain. Ten burials - also indigenous, based on their modified skulls - were found on a more secluded spot on the beach (Ortega 2002, 18; Veloz Maggiolo 1980, 165-166). Remarkably, all were interred in a Christian fashion, each in extended position and together placed in one straight line. Some burials contained Spanish jars and vessels, while a sub-adult was found in possession of a bronze buckle, that, evidenced by the fabric remains attached, probably formed a complete belt. The funerary pattern seems to indicate a collective burial, probably done by Spaniards, who would have allowed family members of the deceased to inter a small number of valuables. As the skeletons do not show any traces of violence, their death has been suggested the result of an epidemic outbreak.

More Spanish objects were found throughout the site, both on the surface and in lower levels (García Arévalo 1978a; García Arévalo 1991; Goggin 1968; Ortega 1982, 165; Veloz Maggiolo 1993, 171). These included hundreds of ceramic fragments, representing various types of majolica, early-style olive jar, and other glazed wares, as well as several extraordinary transcultural pieces (Figure 3.3a). Among these are two unique local manufactures of Spanish bacines or chamber pots, dated between 1514 and 1520 , which clearly show the retention of indigenous decorative techniques and zoomorphic stylistic elements (Veloz Maggiolo 1993, 171). Another pot is typically indigenous in

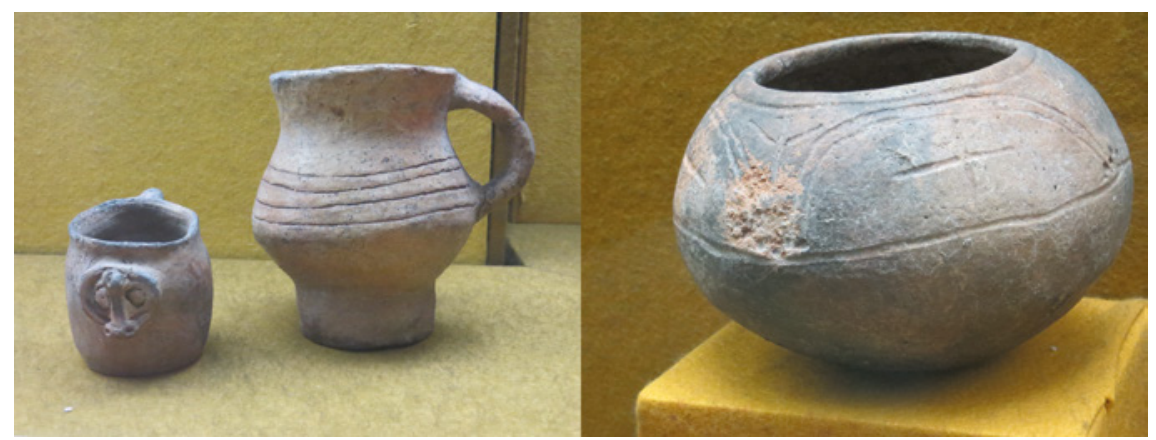

FIGURE 3.3 Early colonial ceramic forms found at Juan Dolio, San Pedro de Macorís, Dominican Republic: (a) indigenous-made pots reflecting Spanish designs; (b) indigenous pot with atypical cross incision. Fundación García Arévalo, Santo Domingo, Dominican Republic PHOTOS BY FLORIS W.M. KEEHNEN, NOT TO SCALE 
form and design, but features atypical incisions showing the sign of a cross, possibly reflecting the influence of Christianity among the indigenous peoples of this region (García Arévalo 1978a, 115; García Arévalo and Morbán Laucer 1971; Morbán Laucer and García Arévalo 1971) (Figure 3.3b). An even more stunning find, perhaps, is the recovery of two metal threepointers or cemis (García Arévalo 1978a, 107). Threepointers were highly ritualized, animated objects within indigenous Caribbean societies, and appear in the archaeological record in various materials, sizes, and degrees of refinement (Breukel 2013; Walker 1997). These two examples, however, are completely incomparable in their way of manufacturing. The larger one is cast with a mold, the slightly smaller one hammered.

Indigenous peoples took possession of European artifacts in a number of ways. Best documented (ethno)historically are direct exchanges with the Spanish in gift-giving and barter events. These were either politically motivated elite affairs or more informal haphazard transactions that also involved other group members. Through indigenous exchange networks European goods were distributed to communities that were not in direct contact with the Spanish (e.g., Hofman et al. 2014). ${ }^{4}$ Other means of acquisition may have included pilfering or the collecting of items lost or otherwise left behind by Spaniards, trophies gained in combat, and shipwreck salvage (Hally and Smith 2010; see also Berman and Gnivecki this volume). Determining the distribution mechanism from a small assemblage of archaeological materials with a poor context is difficult, although the different types of recovered artifacts may provide some clues. Spanish ceramics as well as small glass and metal items including beads, hawk bells, and pins are the strongest indicators of direct indigenousEuropean exchanges. Less typical trade goods such as nails, horseshoes, the lamp base from Sabana Yegua, the key from Juan Barón, and the book clasp from Las Lagunas may be indications of indigenous pilfering or Spanish loss

4 Although down-the-line exchange of European objects is not easily identifiable archaeologically, it is presumed to have been common practice. Columbus directly hints at such indirect trade when navigating through the Bahamas. Here, he describes an encounter with a man in a canoe who is carrying coins (blancas) and glass beads previously received from the Spanish expedition to a neighboring island (Dunn and Kelley 1989, 83-85; see also Berman and Gnivecki this volume). Furthermore, European potsherds have been found on a number of Bahamian islands not known to have been visited by Spanish explorers (Keegan and Mitchell 1987). 
of artifacts. Military items such as musket balls, scabbard tips, and the metal point from Los Balatases might have been taken from defeated enemies on the battlefield (see Table 3.1).

Investigating the site and find contexts of such objects is required to better grasp their place within indigenous societies. The case studies presented above have shown different ways in how their materiality is expressed in the archaeological record. In most of the sites known thus far, as is clearly demonstrated in the case of En Bas Saline, the quantity of European goods is remarkably small, despite their sometimes close proximity to Spanish towns such as Puerto Real. For Deagan, the apparently limited adoption of Spanish items into the material life of the En Bas Saline inhabitants supports the idea of the indigenous "indifference to and rejection of Spanish cultural elements and values" $(2004,621)$. Indeed, the lack of European artifacts in early colonial indigenous contexts cannot be easily explained, certainly not if we take into account the many and rich (ethno)historical descriptions of intercultural gift-giving and exchange. In fact, reading these sources would make it hard to believe that indigenous Caribbean peoples were not receptive of the exotic items they were offered - and actively sought after. It is possible, however, that the possession and circulation of European objects were controlled by indigenous elites. The idea of restricted access is confirmed at the site of En Bas Saline, where almost all of the European materials were found in elite contexts. Especially in the earliest years of colonial interaction, such objects would have been relatively scarce, and rather than being discarded casually, would have been incorporated into indigenous exchange networks. Likewise, Spanish chronicler Gonzalo Fernández de Oviedo narrates the redistribution of the material wealth of a deceased chief to foreign caciques, gifts that might well have included possessions of European origin (see Oliver 2009, 103-108).

The cache of materials found at El Variar indicates European artifacts were sometimes carefully stowed away, probably to be recovered later. The direct association of brass materials with high-value indigenous paraphernalia suggests the metal objects were given an at least similar esteem. The special valuation of European metals by indigenous Caribbean peoples has been suggested by various authors, particularly for the material's gleaming surface (also seen in glass and glazed ceramics), its peculiar smell, as well as its symbolic correlation with - and possible metaphorical substitution of - the indigenous copper alloy known as guanín (Keehnen 2011; Martinón-Torres et al. 2007; Oliver 2000; Saunders 1999; Valcárcel Rojas and Martinón-Torres 2013; Vega 1979). The finding of a metal base of a lamp as part of a cache found at Sabana Yegua probably best illustrates that it was, indeed, the material traits, perhaps including 
its oxidizing and durable properties, instead of the form or function of metal objects that attracted indigenous attention. ${ }^{5}$ Furthermore, as mentioned earlier, brass hawk bells are described as items of special interest in the (ethno)historical sources (García Arévalo and Chanlatte Baik 2015). Columbus writes: "they desired nothing else as much as bells" and "they are on the point of going crazy for them" (Dunn and Kelley 1989, 283), a preference indigenous traders communicated by imitating the tinkling sound. Yet, notwithstanding their initial desirability, the indigenous connotation of European metals may have changed negatively in the course of the colonial process. The Spanish imposition of a tribute system within years after their arrival required each person to pay a hawk bell filled with gold every three months. In addition, a small metal disk had to be hung around the person's neck as a proof of payment (Las Casas 1986, 437). Possibly, the perforated brass items of El Variar are such tokens. The indigenous revaluation of European metals as a result of these colonial measures is not unthinkable, although such a shift cannot be discerned from the archaeological record.

Quite the opposite seems to be reflected in Juan Dolio, where the extraordinary find of the metal threepointers shows the most exquisite way in which European objects were reworked into indigenous forms. Whereas in El Variar pieces of brass were used to decorate indigenous amulets, in Juan Dolio metals are modified to create entirely new objects traditional of indigenous Caribbean society. It cannot be said, however, whether these threepointers were made by indigenous peoples having acquired European techniques, or by Spaniards perhaps aiming to gain favor from the local indigenous population. Juan Dolio shows the characteristics of having been occupied longer than most other sites, possibly indicating the existence of a Spanish outpost or plantation. Here again, the sporadic inclusion of European goods into indigenous graves suggests status differentiation in privileged access to exotic items. The deliberate deposition of European objects with the deceased likely involved a range of different meanings and motives. At least, their integral and personal connection to death and the spiritual afterlife, strongly indicates the special value indigenous peoples placed upon European goods. From the fabric remains found in association with the bronze buckle it can be assumed

5 In addition to metal objects, also glazed ceramics appear to have been valued mostly for their unique material characteristics. Rather than as complete vessels, most Spanish pottery was exchanged as (deliberately) broken pieces, as several of the (ethno)historical documents describe (Dunn and Kelley 1989, 71, 93, 109, 265; Farina and Zacher 1992, 53; MacNutt 1912, 61). Archaeologically, intact vessels have not been recovered either. 
some individuals were buried in Spanish clothing, a practice that has been described for the Cuban site of El Chorro de Maíta (ca. AD 1200 to post-AD 1550) (Martinón-Torres et al. 2007; Valcárcel Rojas et al. 2010). For the Spanish, the offering of clothes and shirts was part of their effort to civilize their indigenous hosts. At the same time, wearing European dress could have been an expression of status and identity among indigenous peoples.

\section{5}

\section{Concluding Remarks}

The Spanish arrival to Hispaniola is archaeologically reflected in a limited though virtually island-wide dispersal of European goods, which appear in a variety of indigenous contexts in a range of different types and forms. European materials either appear as relatively scattered finds, as directly associated with valuable indigenous objects or as integrated parts of highly symbolic icons of indigenous culture and society. A small part of the entire assemblage consists of reworked or physically altered artifacts, some modified as to be attached to or become part of indigenous objects, as in the case of El Variar. Hybrid forms in which indigenous and European shapes, materials, and techniques are brought together, such as at Juan Dolio, are uncommon. The same holds true for weapons, tools, and other implements that are indicative of purely colonial interactions.

Most of the items recovered from sites on Hispaniola pertain to a category of goods generally associated with gift-giving and barter exchanges characteristic of the initial phase of indigenous-European interaction, a short period during which indigenous peoples freely added Spanish objects to existing material culture repertoires. Considering, in addition, the frequently coastal locations of many of these sites, such object assemblages probably point to short, occasional instances of direct interaction between local villages and bypassing Europeans, or, alternatively, down-the-line exchange through preexisting indigenous networks. More regular or sustained interaction between local communities and Spanish settlers likely took place in and around early Spanish centers such as La Isabela, Santo Domingo, and Cotuí, in the immediate vicinity of which relatively high concentrations of indigenous sites with European materials seem to appear. In these cases, colonists may have appealed to the inhabitants of nearby villages for food and other provisions, as well as labor needed for construction works or mining. The local adoption of foreign traits transformed existing repertoires and practices at locations such as Juan Dolio, where indigenous and European peoples either lived together 
or were in day-to-day contact. Also the cache of objects at El Variar may date to a somewhat later stage in the colonial process, reflecting a personal set of valuables taken along by an individual seeking refuge in an attempt to escape colonial power.

The symbolic-ideological qualities indigenous peoples recognized in the distinct materialities of these foreign articles facilitated their adoption and incorporation into the socio-material world of the original island inhabitants. The insertion of European artifacts into indigenous graves, caches, and (sacred) caves, as well as their connection to ceremonial plazas and elite households suggests a certain exclusivity in terms of their access and handling. Such a symbolic importance is further attested by the ritual portrayal of European elements on cave walls. On the other hand, the indigenous integration and recontextualization of European artifacts was part of a dynamic process of (re)negotiation in which previously ascribed meanings and attributed uses may well have been discarded or altered.

Ongoing interaction with Spaniards during the colonial period and the connection and integration of the two different material realms accelerated a process of change and entanglement that was initiated during the encounter. Indigenous peoples not only started to wear European dress, but would also have manufactured new forms of ceramics, adapted their culinary traditions, changed their burial customs, and perhaps would have been open to new beliefs. The indigenous adoption and possible rejection of European artifacts occurred on the basis of their conscious, selective, and varied treatment, and affected different domains of life and death. The transition to a colonial situation in the first decades following contact possibly limited indigenous decision-making autonomy. At the same time, the blending of indigenous and European cultural and material elements does attest to the new and flexible ways indigenous Caribbean communities were able to creatively transform their material culture repertoires over the course of the colonial process.

\section{Acknowledgments}

The research of which this chapter is the result was supported by the Netherlands Organisation for Scientific Research (PhDs in the Humanities 'Values and Valuables in the Early Colonial Caribbean', grant PGW-13-02), and is supervised by Corinne L. Hofman. I thank Hayley Mickleburgh and Andrzej Antczak for their comments on earlier versions of the manuscript. 


\section{References}

Abreu Collado, Domingo. 2008. "El Arte Rupestre Y Fray Ramón Pané." Boletín Del Museo Del Hombre Dominicano 42: 323-330.

Abreu Collado, Domingo, and Harold Olsen Bogaert. 1989. "La Prospección: Elemento Indispensable Para La Arqueología Científica." Boletín Del Museo Del Hombre Dominicano 22: $65^{-81}$.

Atiles, Gabriel. 2004. "Excavaciones Arqueológicas de Punta Macao. Informe de Campo." Manuscript on file, Museo del Hombre Dominicano, Santo Domingo.

Boyrie Moya, Emile E. de. 196o. Cinco Años de Arqueología Dominicana. Santo Domingo: Universidad de Santo Domingo.

Brain, Jeffrey P. 1975. "Artifacts of the Adelantado." In Conference on Historic Site Archaeology Papers 8, edited by Stanley South, 129-138. Columbia: South Carolina Institute of Archaeology and Anthropology.

Breukel, Thomas W. 2013. "Threepointers on Trial: A Biographical Study of Amerindian Ritual Artefacts from the Pre-Columbian Caribbean." Research Master thesis, Leiden University.

Caro Alvarez, José A. 1973. “La Isabela." Boletín Del Museo Del Hombre Dominicano 3: $48-52$.

Chanlatte Baik, Luis A. 1978. "Informe Sanate-Higuey: Arqueología Colonial." Boletín Del Museo Del Hombre Dominicano 10: 133-138.

Cherubin, Ginette. 1991. “Le Project 'Recherche de Navidad' Révélateur D’un Avenir Archéologique Prometteur Pour Haiti." In Proceedings of the 14th Congress of the International Association for Caribbean Archaeology, edited by Alissandra Cummins and Philippa King, 425-435. Barbados: The Barbados Museum and Historical Society.

Cipolla, Craig N., ed. 2017. Foreign Objects: Rethinking Indigenous Consumption in American Archaeology. Tucson: University of Arizona Press.

Cusick, James G. 1991. "Culture Change and Pottery Change in a Taíno Village." In Proceedings of the 13th Congress of the International Association for Caribbean Archaeology, edited by Edwin N. Ayubi and Jay B. Haviser, 1: 446-461. Willemstad, Curaçao: Archaeological-Anthropological Institute of The Netherlands Antilles.

Deagan, Kathleen A. 1987. "Initial Encounters: Arawak Responses to European Contact at the En Bas Saline Site, Haiti." In Proceedings of the ist San Salvador Conference: Columbus and His World, edited by Donald T. Gerace, 341-359. Fort Lauderdale: College Center of the Finger Lakes and San Salvador: Bahamian Field Station.

Deagan, Kathleen A. 1988. "The Archaeology of the Spanish Contact Period in the Caribbean." Journal of World Prehistory 2 (2): 187-233.

Deagan, Kathleen A. 1989. "The Search for La Navidad, Columbus's 1492 Settlement." In First Encounters: Spanish Explorations in the Caribbean and the United States, 
1492-1570, edited by Jerald T. Milanich and Susan Milbrath, 41-54. Gainesville: University of Florida Press.

Deagan, Kathleen A. 1990. "The Search for La Navidad in a Contact Period Arawak Town on Haiti's North Coast." In Proceedings of the nth Congress of the International Association for Caribbean Archaeology, edited by Agamemnon G. Pantel Tekakis, Iraida Vargas Arenas, and Mario Sanoja Obediente, 453-458. San Juan: La Fundación Arqueológica, Antropológica e Histórica de Puerto Rico.

Deagan, Kathleen A., ed. 1995. Puerto Real: The Archaeology of a Sixteenth-Century Spanish Town in Hispaniola. Gainesville: University Press of Florida.

Deagan, Kathleen A. 2003. "Colonial Origins and Colonial Transformations in Spanish America." Historical Archaeology 37 (4): 3-13.

Deagan, Kathleen A. 2004. "Reconsidering Taíno Social Dynamics after Spanish Conquest: Gender and Class in Culture Contact Studies." American Antiquity 69 (4): $597-626$.

Deagan, Kathleen A., and José M. Cruxent. 2002a. Columbus's Outpost among the Taínos: Spain and America at La Isabela, 1493-1498. New Haven: Yale University Press.

Deagan, Kathleen A., and José M. Cruxent. 2002b. Archaeology at La Isabela: America's First European Town. New Haven: Yale University Press.

Domínguez, Lourdes S. 1978. "La Transculturación En Cuba (S. XVI-XVII)." Cuba Arqueológica 1: 33-50.

Domínguez, Lourdes S. 1984. Arqueología Colonial Cubana: Dos Estudios. Havana: Editorial de Ciencias Sociales.

Drusini, Andrea, Ferdinando Businaro, and Fernando Luna Calderón. 1987. "Skeletal Biology of the Taíno: A Preliminary Report." International Journal of Anthropology 2 (3): $247-253$.

Dunn, Oliver, and James E. Kelley, eds. 1989. The Diario of Christopher Columbus's First Voyage to America 1492-1493. Abstracted by Fray Bartolomé de Las Casas. Translated by Oliver Dunn and James E. Kelley. Norman: University of Oklahoma Press.

Ernst, Marlieke, and Corinne L. Hofman. 2015. "Shifting Values: A Study of Early European Trade Wares in the Amerindian Site of El Cabo, Eastern Dominican Republic." In GlobalPottery 1: Historical Archaeology and Archaeometry for Societies in Contact, edited by Jaume Buxeda i Garrigós, Marisol Madrid i Fernández, and Javier Garcia Iñañez, 195-204. Oxford: Archaeopress.

Florida Museum of National History. 2017. “Artifact Gallery." Accessed June 1. http:// www.flmnh.ufl.edu/histarch/artifactGallery.asp.

García Arévalo, Manuel A. 1978a. "La Arqueología Indo-Hispana En Santo Domingo." In Unidad YVariedad: Ensayos Antropológicos En Homenaje a José M. Cruxent, edited by Erika Wagner and Alberta Zucchi, 77-127. Caracas: Instituto Venezolano de Investigaciones Científicas. 
García Arévalo, Manuel A. 1978b. "Influencias de La Dieta Indo-Hispanica En La Cerámica Taína." In Proceedings of the 7 th International Congress for the Study of the Pre-Columbian Cultures of the Lesser Antilles, edited by Ripley P. Bullen, 263-277. Montreal: Centre de Recherches Caraïbes, Université de Montréal.

García Arévalo, Manuel A. 1990. "Transculturation in Contact Period and Contemporary Hispaniola." In Archaeological and Historical Perspectives on the Spanish Borderlands East, edited by David Hurst Thomas, 269-280. Columbian Consequences, Vol. 2. Washington, DC: Smithsonian Institution Press.

García Arévalo, Manuel A. 1991. "Influencias Hispánicas En La Alfarería Taína." In Proceedings of the 13th Congress of the International Association for Caribbean Archaeology, edited by Edwin N. Ayubi and Jay B. Haviser, 363-383. Willemstad, Curaçao: Archaeological-Anthropological Institute of the Netherlands Antilles.

García Arévalo, Manuel A., and Luis A. Chanlatte Baik. 2015. "Los Cascabeles O Sonajeros Taínos." In Proceedings of the 25th International Congress for Caribbean Archaeology, edited by Laura del Olmo, 6o9-613. San Juan: Instituto de Cultura Puertorriqueña, el Centro de Estudios Avanzados de Puerto Rico y el Caribe y la Universidad de Puerto Rico, Recinto de Río Piedras.

García Arévalo, Manuel A., and Fernando Morbán Laucer. 1971. "Localizan Fosa Que Pertenecía A Los Indígenas." El Caribe, January 19.

García Arévalo, Manuel A., and Fernando Morbán Laucer. 1990. "La Plaza O Batey Aborigen de Yamasá." Boletín Del Museo Del Hombre Dominicano 23: 79-96.

Goggin, John M. 1960. The Spanish Olive Jar: An Introductory Study. New Haven: Department of Anthropology, Yale University.

Goggin, John M. 1968. Spanish Majolica in the New World: Types of the Sixteenth to Eighteenth Centuries. New Haven: Department of Anthropology, Yale University.

Gosden, Chris. 2004. Archaeology and Colonialism: Cultural Contact from 5000 BC to the Present. Cambridge: Cambridge University Press.

Guerrero, José G. 1999. "Una Lectura Arqueo-Histórica Del Contacto Temprano IndoEuropeo: El Caso de La Isabela, Primera Villa de América." Boletín Del Museo Del Hombre Dominicano 27: 97-109.

Guerrero, José G., and Marcio Veloz Maggiolo. 1988. Los Inicios de La Colonización En América: La Arqueología Como Historia. San Pedro de Macorís: Universidad Central del Este.

Hally, David J., and Marvin T. Smith. 2010. "Sixteenth-Century Mechanisms of Exchange." Journal of Global Initiatives: Policy, Pedagogy, Perspective 5 (1): 53-65.

Hatt, Gudmund. 1932. "Notes on the Archaeology of Santo Domingo." Geografisk Tidsskrift 35 (1/2): 9-17.

Hofman, Corinne L., Angus A.A. Mol, Menno L.P. Hoogland, and Roberto Valcárcel Rojas. 2014. "Stage of Encounters: Migration, Mobility and Interaction in the PreColonial and Early Colonial Caribbean." World Archaeology 46 (4): 590-6o9. 
Keegan, William F. 2001. "Archaeological Investigations on Ile À Rat, Haiti." In Proceedings of the 18th Congress of the International Association for Caribbean Archaeology, Volume 2, edited by The International Association for Caribbean Archaeology, Region Guadeloupe, 233-239. St. George, Grenada.

Keegan, William F., and Steven W. Mitchell. 1987. "The Archaeology of Christopher Columbus' Voyage Through the Bahamas, 1492." American Archaeology 6 (2):102-108.

Keehnen, Floris W.M. 2011. "Conflicting Cosmologies: The Exchange of Brilliant Objects between the Taíno of Hispaniola and the Spanish." In Communities in Contact: Essays in Archaeology, Ethnohistory \& Ethnography of the Amerindian Circum-Caribbean, edited by Corinne L. Hofman and Anne Van Duijvenbode, 253-268. Leiden: Sidestone Press.

Keehnen, Floris W.M. 2012. "Trinkets (f)or Treasure? The Role of European Material Culture in Intercultural Contacts in Hispaniola during Early Colonial Times." Research Master thesis, Leiden University.

Keehnen, Floris W.M., and Angus A.A. Mol. 2018. "The Roots of the Columbian Exchange: An Entanglement and Network Approach to Early Caribbean Encounter Transactions." Unpublished manuscript, Faculty of Archaeology, Leiden University.

Krieger, Herbert W. 1929. Archaeological and Historical Investigations in Samaná, Dominican Republic. Washington, D.C.: United State Government Printing Office.

Kulstad, Pauline M. 2008. "Concepción de La Vega 1495-1564: A Preliminary Look at Lifeways in the Americas' First Boom Town." Master thesis, University of Florida.

Kulstad, Pauline M. 2015. "Striking It Rich in the Americas' First Boom Town: Economic Activity at Concepción de La Vega (Hispaniola) 1495-1564." In Archaeology of Culture Contact and Colonialism in Spanish and Portuguese America, edited by Pedro P.A. Funari and Maria X. Senatore, 313-337. Cham: Springer.

Las Casas, Bartolomé de. 1986. Historia de Las Indias. Edited by André Saint-Lu. Vol. 1. Caracas: Biblioteca Ayacucho.

Lightfoot, Kent G., Antoinette Martinez, and Ann M. Schiff. 1998. "Daily Practice and Material Culture in Pluralistic Social Settings: An Archaeological Study of Culture Change and Persistence from Fort Ross, California." American Antiquity 63 (2): 199-222.

López Belando, Adolfo José. 20og. "El Arte Rupestre En El Parque Nacional Los Haitises." Rupestreweb. http://www.rupestreweb.info/haitises2.html.

López Belando, Adolfo José., ed. 2012. "El Sitio Arqueológico de Playa Grande, Rio San Juan, María Trinidad Sánchez: Informe de Las Excavaciones Arqueológicas Campaña 2011-2012." Manuscript on file, Museo del Hombre Dominicano, Santo Domingo. López Belando, Adolfo José. 2015. "Excavaciones Arqueológicas En El Poblado Taíno de Playa Grande, República Dominicana." In Proceedings of the 25th Congress of the International Association for Caribbean Archaeology, edited by Laura Del Olmo, 254-279. San Juan: Instituto de Cultura Puertorriqueña, el Centro de Estudios 
Avanzados de Puerto Rico y el Caribe y la Universidad de Puerto Rico, Recinto de Río Piedras.

López Rojas, Elba. 1990. "Informe de Un Viaje de Prospección Al Parque Nacional Jaragua - 1987." Boletín Del Museo Del Hombre Dominicano 23: 41-53.

Luna Calderón, Fernando. 1986. "El Cementerio de La Isabela: Primera Villa Europea Del Nuevo Mundo: Estudio de Antropología Física." Primera Jornada de Antropología 1 (1): 10-17.

Mañón Arredondo, Manuel J. 1978. "Importancia de Los Ingenios Indo-Hispánicos de Las Antillas." Boletín Del Museo Del Hombre Dominicano 10: 139-164.

Mañón Arredondo, Manuel J., Fernando Morbán Laucer, and Aida Cartagena Portalatín. 1971. "Nuevas Investigaciones de Áreas Indígenas Al Noreste de Guayacanes Y Juan Dolio." Revista Dominicana de La Arqueología Y Antropología 1 (1): 81-113.

Maran, Joseph, and Philipp W. Stockhammer, eds. 2012. Materiality and Social Practice: Transformative Capacities of Intercultural Encounters. Oxford: Oxbow Books.

Martinón-Torres, Marcos, Roberto Valcárcel Rojas, Jago Cooper, and Thilo Rehren. 2007. "Metals, Microanalysis and Meaning: A Study of Metal Objects Excavated from the Indigenous Cemetery of El Chorro de Maíta, Cuba." Journal of Archaeological Science 34: 194-204.

Morbán Laucer, Fernando, and Manuel A. García Arévalo. 1971. "Describen Hallazgos Objetos Indígenas." Listín Diario, January 21.

Oliver, José R. 200o. "Gold Symbolism among Caribbean Chiefdoms: Of Feathers, Çibas and Guanín Power among Taíno Elites." In Precolumbian Gold: Technology, Style and Iconography, edited by Colin McEwan, 196-219. London: British Museum Press.

Oliver, José R. 2009. Caciques and Cemí Idols: The Web Spun by Taíno Rulers Between Hispaniola and Puerto Rico. Tuscaloosa: University of Alabama Press.

Olsen Bogaert, Harold, ed. 2011. "Sitio Arqueológico No. 11: Investigación Estructuras Coloniales." Manuscript on file, Museo del Hombre Dominicano, Santo Domingo.

Olsen Bogaert, Harold. 2013a. "Prospección Y Registro de Sitios Arqueológicos En Pueblo Viejo de Cotuí 2003-2010." Boletín Del Museo Del Hombre Dominicano 45: 121-150.

Olsen Bogaert, Harold., ed. 2013b. "Investigación Sitio Arqueológico No. 17: El Rayo." Manuscript on file, Museo del Hombre Dominicano, Santo Domingo.

Olsen Bogaert, Harold. 2015. "Inventario de La Selección de Bienes de Las Investigaciones Arqueológicas En El Proyecto Pueblo Viejo de Cotuí, Y Su Entorno.” Manuscript on file, Museo del Hombre Dominicano, Santo Domingo.

Olsen Bogaert, Harold, Francisco Coste, and Jiménez L. Abelardo 2011. "Estructuras Coloniales En La Mina de Oro de Pueblo Viejo, Cotuí, Provincia Sánchez Ramírez." Boletín Del Museo Del Hombre Dominicano 44: 39-73.

Olsen Bogaert, Harold, Eugenio Pérez Montás, and Esteban Prieto Vicioso, eds. 1998. Arqueología Y Antropología Física En La Catedral de Santo Domingo. Santo Domingo: Centro de Altos Estudios Humanisticos y del Idioma Español. 
Ortega, Elpidio J. 1978. "Informe Sobre Investigaciones Arqueológicas Realizadas En La Región Este Del País, Zona Costera Desde Macao a Punta Espada." Boletín Del Museo Del Hombre Dominicano 11: 77-105.

Ortega, Elpidio J. 1980. Introducción a La Loza Común O Alfarería En El Período Colonial de Santo Domingo. Santo Domingo: Fundación Ortega Álvarez.

Ortega, Elpidio J. 1982. Arqueología Colonial En Santo Domingo. Santo Domingo: Taller. Ortega, Elpidio J. 2002. Artefactos En Concha: Arqueología En Coral Costa Caribe, Juan Dolio, R.D. Santo Domingo: Fundación Ortega Álvarez.

Ortega, Elpidio J. 2005. Compendio General Arqueológico de Santo Domingo, Vol. ı. Santo Domingo: Academia de Ciencias de la República Dominicana.

Ortega, Elpidio J., and Carmen G. Fondeur. 1976. Primer Informe Sobre Piezas Metálicas Indígenas En Barrera. Santo Domingo: Centro Dominicano de Investigaciones Antropológicas.

Ortega, Elpidio J., and Carmen G. Fondeur. 1978. Estudio de La Cerámica Del Período Indo-Hispana de La Antigua Concepción de La Vega. Santo Domingo: Taller.

Ostapkowicz, Joanna. 2013. "Made ... With Admirable Artistry': The Context, Manufacture and History of a Taíno Belt." The Antiquaries Journal 93: 287-317.

Pagán Perdomo, Dato. 1999. "El Estudio Del Arte Rupestre En La Isla de Santo Domingo." Boletín Del Museo Del Hombre Dominicano 27: 19-43.

Samson, Alice V.M. 2010. Renewing the House: Trajectories of Social Life in the Yucayeque (Community) of El Cabo, Higüey, Dominican Republic, AD 800 to 1504. Leiden: Sidestone Press.

Samson, Alice V.M., Jago Cooper, and Josué Caamaño-Dones. 2016. "European Visitors in Native Spaces: Using Paleography to Investigate Early Religious Dynamics in the New World." Latin American Antiquity 27 (4): 443-461.

Saunders, Nicholas J. 1999. "Biographies of Brilliance: Pearls, Transformations of Matter and Being, C. AD 1492." World Archaeology 31 (2): 243-257.

Schomburgk, Robert H. 1854. "Ethnological Researches in Santo Domingo." Journal of the Ethnological Society of London 3: 115-122.

Silliman, Stephen W. 2010. "Indigenous Traces in Colonial Spaces: Archaeologies of Ambiguity, Origin, and Practice." Journal of Social Archaeology 10 (1): 28-58.

Smithsonian National Museum of Natural History. 2017. "Department of Anthropology Collections.” Accessed June 1. http://collections.nmnh.si.edu/search/anth/.

Tavárez María, Glenis. 2000. "El Ingenio Diego Caballero: Aspectos Históricos Y Culturales de Una Factoría Azucarera Del Siglo XVI." Boletín Del Museo Del Hombre Dominicano 28: 65-75.

Taylor, Dicey, Marco Biscione, and Peter G. Roe. 1997. "Epilogue: The Beaded Zemi in the Pigorini Museum." In Taino: Pre-Columbian Art and Culture from the Caribbean, edited by Fatima Bercht, Estrellita Brodsky, John A. Farmer, and Dicey Taylor, 158169. New York: The Monacelli Press. 
Thomas, Nicholas. 1991. Entangled Objects: Exchange, Material Culture and Colonialism in the Pacific. Cambridge: Harvard University Press.

Ulloa Hung, Jorge, and Eduardo Herrera Malatesta. 2015. "Investigaciónes Arqueológicas En El Norte de La Española, Entre Viejos Esquemas Y Nuevos Datos." Boletín Del Museo Del Hombre Dominicano 46: 75-107.

Valcárcel Rojas, Roberto. 1997. "Introducción a La Arqueología Del Contacto IndoHispánico En La Provincia de Holguín, Cuba." El Caribe Arqueológico 2: 64-77.

Valcárcel Rojas, Roberto. 2016. Archaeology of Early Colonial Interaction at El Chorro de Maíta, Cuba. Gainesville: University of Florida Press.

Valcárcel Rojas, Roberto, and Marcos Martinón-Torres. 2013. "Metals in the Indigenous Societies of the Insular Caribbean." In The Oxford Handbook of Caribbean Archaeology, edited by William F. Keegan, Corinne L. Hofman, and Reniel Rodríguez Ramos, 504-522. Oxford: Oxford University Press.

Valcárcel Rojas, Roberto, Marcos Martinón-Torres, Jago Cooper, and Thilo Rehren. 2010. "Turey Treasure in the Caribbean: Brass and Indo-Hispanic Contact at El Chorro de Maíta, Cuba." In Beyond the Blockade: New Currents in Cuban Archaeology, edited by Susan Kepecs, L. Antonio Curet, and Gabino La Rosa Corzo, 106-125. Tuscaloosa: University of Alabama Press.

Valcárcel Rojas, Roberto, Alice V.M. Samson, and Menno L.P. Hoogland. 2013. "IndoHispanic Dynamics: From Contact to Colonial Interaction in the Greater Antilles." International Journal of Historical Archaeology 17 (1): 18-39.

VanderVeen, James M. 2006. "Subsistence Patterns as Markers of Cultural Exchange: European and Taíno Interactions in the Dominican Republic." PhD diss., Indiana University.

Vega, Bernardo. 1973. "Un Cinturón Tejido Y Una Careta de Madera de Santo Domingo, Del Período de Transculturación Taíno-Español." Boletín Del Museo Del Hombre Dominicano 3: 199-226.

Vega, Bernardo. 1979. Los Metales Y Los Aborígenes de La Hispaniola. Santo Domingo: Museo del Hombre Dominicano.

Vega, Bernardo, and Fernando Luna Calderón. 2004. "Descubrimiento de La Primera Plaza Indígena En La Isla Saona." Boletín Del Museo Del Hombre Dominicano 36: 31-34.

Veloz Maggiolo, Marcio. 1972. Arqueología Prehistórica de Santo Domingo. Singapore: McGraw-Hill Far Eastern Publishers.

Veloz Maggiolo, Marcio. 1980. Vida Y Cultura En La Prehistoria de Santo Domingo. San Pedro de Macorís: Universidad Central del Este.

Veloz Maggiolo, Marcio. 1993. La Isla de Santo Domingo Antes de Colón. Santo Domingo: Banco Central de la República Dominicana.

Veloz Maggiolo, Marcio, Elpidio J. Ortega, Renato O. Rimoli, and Fernando Luna Calderón. 1973. "Estudio Comparativo Y Preliminar de Dos Cementerios Neo-Indios: La 
Cucama Y La Unión, República Dominicana." Boletín Del Museo Del Hombre Dominicano 3: 11-47.

Veloz Maggiolo, Marcio, Iraida Vargas, Mario Sanoja, and Fernando Luna Calderón. 1976. Arqueología de Yuma (República Dfdominicana). Santo Domingo: Taller.

Walker, Jeffrey B. 1997. "Taíno Stone Collars, Elbow Stones, and Three-Pointers." In Taíno: Pre-Columbian Art and Culture from the Caribbean, edited by Fatima Bercht, Estrellita Brodsky, John A. Farmer, and Dicey Taylor, 80-91. New York:The Monacelli Press.

Wilson, Samuel M. 1990. Hispaniola: Caribbean Chiefdoms in the Age of Columbus. Tuscaloosa: University of Alabama Press. 